\title{
Blind men and the elephant: one view of the field of migration studies
}

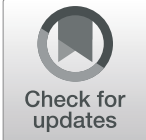

Josh DeWind

Correspondence: joshdewind@ gmail.com

Social Science Research Council, New York, USA

\section{Abstract \\ There are many ways to conceive and represent the field of migration studies. The CrossMigration article provides us with a broad overview to help us understand and contribute to the field's development. This article explores a number of additional and complementary views drawn from the field-building activities of the Social Science Research Council between 1994 and 2014.

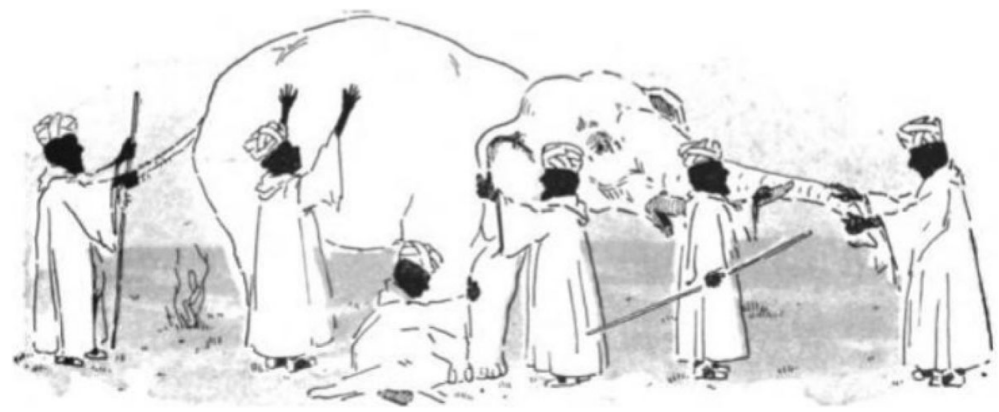 \\ (Source: Charles Maurice Stebbins \& Mary H. Coolidge, Golden Treasury Readers: Primer, American Book Co., New York, 1909, p. 89. For the story of the "Blind Men and the Elephant," see pp. 87-91: https://books.google.com/books?id=_dlAAAAAYAAJ\&pg= PA89\#v=onepage\&q\&f=false:)}

Keywords: Migration, International migration, Migration theory, Migration studies, Social Science Research Council

\section{Introduction}

If the field of migration studies were an elephant, then the Cross-Migration team's paper, "Between Fragmentation and Institutionalization: The Rise of Migration Studies as a Research Field" (Levy et al. 2020) in combination with their earlier paper, "Mapping Migration Studies: An Empirical Analysis of the Coming of Age of a Research Field" (Pisarevskaya et al. 2019), could be said to provide us with an excellent x-ray portrait of the animal's entire skeleton, which shows us how all its boney parts articulate and hang together. Focusing on the first paper, its most striking aspect to me is the database on which its analysis is based comprising information about 48,842 journal articles published between 1975 and 2018, some 9052 organizations, and authors

(c) The Author(s). 2020 Open Access This article is licensed under a Creative Commons Attribution 4.0 International License, which permits use, sharing, adaptation, distribution and reproduction in any medium or format, as long as you give appropriate credit to the original author(s) and the source, provide a link to the Creative Commons licence, and indicate if changes were made. The images or other third party material in this article are included in the article's Creative Commons licence, unless indicated otherwise in a credit line to the material. If material is not included in the article's Creative Commons licence and your intended use is not permitted by statutory regulation or exceeds the permitted use, you will need to obtain permission directly from the copyright holder. To view a copy of this licence, visit http://creativecommons.org/licenses/by/4.0/. 
in 185 countries. This database provides the foundation for the paper's bibliometric analysis of the field's institutionalization as reflected by its increasing self-referentiality, internationalization, and integration between epistemic communities. I call this a "skeletal portrait" because it cannot capture the intellectual engagements and theoretical debates between migration researchers, which are embodied within the journal articles and might, so to speak, put some flesh on the bones and give us a portrait of the living animal. Nonetheless, given the remarkable growth and impressive current size of this elephant, I find myself akin to one of the blind men in the ancient Indian parable who together try to discover what an elephant is like by each feeling its various parts. I am not sure whether I have been at the front or tail end, but by providing an $\mathrm{x}$-ray of the field as a whole, the article and the discussion of it in Lisbon on 5-6 February, 2019, may help us to avoid the blind men's fight over whose perceptions were are true and to see more clearly how our varied individual perspectives can contribute to fuller understanding of the living animal that is supported by its skeleton.

Triangulating between quantitative data, some of the field's literature, and interviews with ten "experts," the Cross-Migration authors have concluded, justifiably, that over four decades the field has grown in size, strengthened its infrastructure, become increasingly self-referential, and internationalized in scope. While I expect the authors do not anticipate these conclusions will surprise many of the field's researchers, they do intend that, by helping us to understand how migration studies has become institutionalized, we will be better prepared to promote its future interdisciplinary development. (p. 2) To contribute to this effort, I offer the perspective of one blind man, whose experiences with the institutionalization of migration studies has been delimited temporally and geographically by having directed the organization of field-building activities at the Social Science Research Council (SSRC) in the United States from 1994 to $2014 .{ }^{1}$ As a result, seeking to add some experiential flesh to the elephant's skeleton, I offer the following series of observations as supplemental, not alternative, to how the CrossMigration team has portrayed of field's institutionalization. Indeed, one of the basic observations that I will make is that there are many different but overlapping visions of the field, each of which is valid, and all of which are integral the field's vitality. (To provide some context for these observations, I attach at the end of this article an Additional file 1 that outlines the Council's varied migration field-building activities from 1994 to 2014).

\section{Institutionalization}

The Cross-Migration authors have set out to determine, "How has migration studies institutionalised in the past four decades?" From their answers to this question, it seems that they have focused on the field's institutionalization because they consider that to be a positive outcome, as did I while directing the SSRC's migration field-building activities. But, if institutionalization means creating "a common theoretical language," "a rather unified and stable conceptual and theoretical foundation," and the "standardization of norms and practices" (pp. 2-3) it also seems that institutionalization can also mean greater homogenization and a breakdown, through what they describe as

${ }^{1}$ The migration field-building activities I directed took place under the auspices of the SSRC's International Migration Program (1994-2006), Migration Program (2006-2009), and Dissertation Proposal Development Program (2009-2014). 
"disciplinary osmosis," of the field's conceptual, theoretical, and disciplinary diversity perhaps even to become "post-disciplinary." (p. 5) Despite this long-term trend, the article's discussion of the field's disciplinary foundations, which is based largely on "expert" interviews, also recognizes how each discipline has entered into, and contributed to, the field's institutionalization.

To understand where we are and how we got here as a field, as the authors propose, it makes sense to examine not only the internal institutionalization between migration researchers but also those researchers' continuing external ties to, and embeddedness within, their different disciplines. Considering migrant researchers' disciplinary ties outside the field raises the question what diversity of perspectives do they draw from the topical, theoretical, and methodological traditions of their disciplines and what does their migration research contribute to the development of those disciplinary traditions?

Related, when the when the SSRC's International Migration Program sponsored a National Survey of Migration Scholars - a view of the field quite different from, but complementary to, the bibliometric approach of the Cross-Migration project - it targeted primarily members of migration sub-sections of national disciplinary associations of history, anthropology, sociology, and political science. It also included the more than 250 multi-disciplinary applicants for the program's research fellowships in 1996 and $1997 .^{2}$ With this survey, and in subsequent research fellows' conferences, it became clear that many migration researchers considered themselves to be members of both their disciplines and the field of migration studies, and that their identification and allegiance shifted back and forth between the field and their disciplines during their careers (Rumbaut 2000). When the International Migration Program Committee considered what final efforts it might make toward the field's institutionalization, its members decided not to create a new migration studies association or journal. The consensus view was that a new association and journal would compete for attendance and publications with the disciplinary associations' migration sub-sections and existing disciplinary journals, which sustain the field's multi-disciplinary diversity.

If institutionalization leads to homogenization within and between epistemic communities of the field as a whole, then we have to wonder whether the field's internationalization is introducing geographically diverse intellectual perspectives or imposing hegemonic paradigms that new researchers must engage in order to become respected contributors to the field? But whether the field's increasing institutionalization reflects or contributes to a diminishment of disciplinary and international intellectual diversity is a question that apparently cannot be determined from the Cross-Migration database, or at least not from increasingly dense co-citations within and between epistemic communities, which the authors point out could result from disagreement and debate as well as consensus (p. 16). Making such a determination would require, at the least, an expanded database, one that includes migration-related articles that are published in disciplinary journals, and examining their contents. One result would be that the larger number of publications and co-citations (or lack of them) would make the field appear not only considerably larger than is indicated

${ }^{2}$ By the fellowship program's end in 2006, it had received 947 applications from junior and senior scholars in sociology (31\%), history (19), anthropology (15), political science (15), demography (3), economics (3), psychology (3), and many other disciplines including ethnic studies, geography urban planning (12). The program awarded 108 research fellowships (Chang and DeWind 2002). https://issuu.com/ssrcitemsissues/ docs/i_i_vol_4_no_1_2003?e=24618429/35326188 
by the Cross-Migration project's 48,842 articles, but also, I anticipate, less self-referential, less intensely institutionalized, and intellectually more diverse than the article suggests.

Whether "hegemonic homogenization" is a cause for concern about the field's future development or not, the point here is that a holistic study of the field can helpfully extend beyond an examination of its institutionalized core to include as well its peripheral relations with disciplines. If I may switch metaphors and propose we think of migration studies as a tree, then to understand the field we need to focus not only on the central trunk of institutionalization and its epistemic branches, whose interconnections the Cross-Migration analysis has made visible, but also on its diffuse system of invisible underground roots, which provide intellectual nutrients from a multi-disciplinary subsoil and sustain the growth and of the trunk and limbs. Put more directly, in seeking to understand where we are as a field and how we got here, we ought to pay attention to what the field draws from and contributes to disciplinary scholarship as well as to the field's increasingly institutionalized core.

\section{Definition(s) of the field}

The article settles on Russell King's empirically sensible definition of the field: "migration studies encompasses research on all types of international and internal migration, migrants, and migration-related diversities (King 2012)." But defining the field on the basis of the migrants and the movements that we study omits the contexts that motivate and, often, enable us to explain migration. ${ }^{3}$ For field-building purposes, I have in the past been partial to a more theoretical definition: that migration studies seeks to explain the origins, processes, and outcomes of migration and that it remains an interdisciplinary field only so long as migration researchers from different disciplines engage one another's explanations. This definition emphasizes the field's basis in social science that is theory-based and seeks to explain - and not just record or describe - migration patterns. But this definition is of course limited and will not satisfy those who hold, legitimately I think, that one of the purposes of migration studies should be to inform public debates and policy making, about which more later.

Researchers based in different disciplines tend to investigate different types of migrants in relation to different topics, different places, and different social contexts and they do so from different scientific or explanatory perspectives. As a result, they also place very different boundaries around what they think should be included or excluded from the field. While King's definition is empirically broad and encompassing, just one definition does not really seem adequate to capture the field's diversity of disciplinary, geographic, topical, and theoretical perspectives. Nonetheless, this definition serves well the purpose of the Cross-Migration project in its bibliometric analysis to document the growth and extent of the field's institutionalization.

The authors recognize that others who have defined and studied the field for different purposes have done so through different analytic lenses: interdisciplinary (Bommes and Morawska 2005), theoretical (Massey et al. 1998; Cohen 1996) and methodological (King 2012). Nonetheless they add that "research with a holistic approach is lacking." (p. 1) Here holistic implies to me that they are taking a broader and more encompassing approach. This claim is likely accurate regarding the size and scope of their

${ }^{3}$ For more on the field's focus on migrants and contexts see DeWind (2019). 
publication database, but not when compared with other ways of conceiving the temporal, geographic, topical, and scholarly content or boundaries of the field.

Temporally, the Cross-Migration project has access to journal data going back only to 1975 , but the origins of migration studies, as the researchers point out, actually goes back at least as far Ravenstein's 1885 "Laws of Migration." In the late 19th and early 20th centuries, massive immigration and public controversies about its effects in the United States, led the Social Science Research Council in 1923 to organize its first of hundreds of interdisciplinary field-building programs, this one titled "Scientific Aspects of Human Migration." The word "scientific" was put into the program's title not only because the SSRC was being formed to legitimize the social sciences as sciences but also, in this case, because this program provided a social science alternative to the biological perspectives of eugenicists, whose claims regarding the deleterious effects of immigration through "race-mixing" were fomenting public support for restrictive immigration policies. Back then, the SSRC defined the geographic scope of the field broadly, to include internal as well as international migration, primarily in the United States but also in other parts of the world (DeWind 2000).

Seven decades later, when the Council organized its second migration studies fieldbuilding program, its geographic and topical scope was at first narrowed to focus exclusively on international migration to the United States. While the program's initial focus on US immigration was set by the funder, the Andrew W. Mellon Foundation, the types of migration to be included was up to the Program Committee. When the committee members debated what types of migration would be considered, one member warned that including internal migration (e.g. the early twentieth century migration of African Americans from the rural south to industrializing northern cities) would "open up a can of worms." Whatever that metaphor might have meant conceptually or theoretically, the committee agreed to examine only international migration to the United States, a narrow scope that was abandoned by the middle of the program's life to include both internal and international migration both within and outside the United States. Despite the widened geographic and topical scope of the SSRC's field-building activities, which were renamed the "Migration Program" to reflect that widening, the Cross-Migration project includes research on a greater number of different types of migration and geographies. Nonetheless, the Cross-Migration database limits its temporal scope in a way that the SSRC's second field-building program could not, because of the earlier waves of migration, research, and field-building efforts. In fact, the program committee created a Sub-Committee on Historical Comparisons in order to organize three working groups that compared past and contemporary immigration and research on the topics of political membership, race and ethnicity, and religion. The resulting publications may in the long-term become one of the committee's more significant contributions to building US immigration studies (Gerstle and Molenkopf 2001; Foner and Fredrickson 2005; Alba et al. 2009).

The point is that definitions and the scope of the field will, and perhaps should, differ according to the questions being asked and the data available to answer them. As seems to be the case for the Cross-Migration project, sometimes the data that is available dictates the scope of topics and questions can be addressed. Because researchers in an interdisciplinary field draw not only on multiple sources of data but also on different histories and traditions of migration studies, competing 
or multiple definitions of the field, which fit different contexts and purposes, ought to be welcomed.

\section{Fragmentation}

While the Cross-Migration project's analysis of co-authorship and co-citations in its database of the field's journals clearly indicates increasing coherence within and between the field's epistemic communities, that coherence may not reveal a continuing fragmentation between disciplines. Taking a wider view of the field's publications, including disciplinary journals and books, might have revealed the persistence of such fragmentation.

When SSRC's International Migration Program was seeking an economist in 1996 to participate in our first conference, the purpose of which was undertake an interdisciplinary assessment of the "state of the art" for theories of migration, I approached the economist David Card, who had recently published an article, with both theoretical and policy implications, about the impact that the recent influx of Cuban refugees had on the wages and employment of native Americans in Miami (Card 1990). Partly because of that study, Card had been awarded the American Economic Association's John Bates Clark Award in recognition of his having made the most significant contribution to the discipline among economists under the age of 40. When I asked him how the notion of an "ethnic enclave," as described in Miami by the sociologist, Alejandro Portes, ${ }^{4}$ might have affected his modeling of the Miami labor market, Card's response was, “....Alejandro who?” Since that time, the Cross-Migration analysis indicates there has been an increase of co-citations linking social and economic research communities within the field. Nonetheless, the gap persists. Even though Portes appears to have been the most frequently cited scholar in the Cross-Migration co-citation networks over the four decades covered by the study (pp. 17-20), Card's 18 publications on immigration omit reference to any of Portes' publications, except for one passing reference to an article co-authored with Min Zhou (Portes and Zhou 1993, in Card et al. 2000).

Surprisingly, despite Card's prominence in the field of migration studies, his name is not visible in the Cross-Migration cross-citation network maps. Perhaps this is because all of Card's immigration writings have appeared in economic publications that were not included in the Cross-Migration databases used to map the field and measure fragmentation and institutionalization ${ }^{5}$. But then, in subsequent articles on immigrant enclaves, Portes did not mention Card's article (Portes and Shafer 2007; Portes and Puhrmann 2015). A decade later, in his book on Economic Sociology: A Systematic Inquiry, where Portes assesses the broader theoretical implications of his research on various aspects of migration, including Miami's Cuban enclave, there is no reference to any of Card's immigration writings on related topics (Portes 2010).

The broader implications of this single anecdote with reference to the analysis of the Cross-Migration large database, as with any anecdote, may be uncertain, but they suggest that the Cross-Migration article's finding of increased cohesion within and

\footnotetext{
${ }^{4}$ Portes had previously published four articles about Miami's Cuban enclave two prominent sociology journals: See Portes (1987); Portes and Jensen (1987); Portes and Jensen (1989); Portes and Jensen (1992). ${ }^{5}$ List of journals in the Cross-Migration project's data bases provided by Nathan Levy, 14 January 2020. For David Card's eighteen publications related to immigration see http://davidcard.berkeley.edu/papers.html\#2.
} 
between epistemic communities at the core of the field may not have fully captured the extent to which disciplinary fragmentation also continues, perhaps particularly with regard to economics but also to parts of other disciplines. But, even if some disciplinary research is somewhat peripheral to the field's core, it can nonetheless remain important to the diversity of perspectives between migration scholars. In other words, even though fragmentation and institutionalization may seem in contradiction with each other, both may be vital to the field's constitution and intellectual development.

\section{Internationalization}

The authors of the Cross-Migration article wrote that, although migration research has traditionally been connected to national histories, narratives, policies, languages, funding, and empirical data, they nonetheless expected to find that:

- contemporary critiques of "methodological nationalism," global communication, and the digitized knowledge infrastructures have resulted in an increasing internationalization of migration studies;

- the field's internationalization is reflected in a growth of international co-authorship but that rates in international co-authorship would, due to disparate research policies and funding structures, prove to be internationally uneven; and

- even though increased "cross-country collaborations may not necessarily mean the end of national paradigms, continued scientific co-operation across borders facilitates a broadening of conceptual and theoretical perspectives, a softening of national models, and, perhaps, a globalisation of migration theory" (p. 4)

Maybe so, but I have some doubts about the actuality and desirability of such a relation between the de-nationalization and the internationalization or globalization of migration studies.

There is good reason for migration studies researchers who are seeking to explain migration to rethink the administrative categories and data that we have received from nation states seeking to manage the flows and impacts of migrants. The legal identities and statuses of individual migrants that distinguish them from national citizens or other migrants (e.g. international and internal migrants, refugee/asylum seekers and other legal and illegal migrants) are not particularly helpful to researchers who seek to understand the movements and networks of migrants as members of a family, community, or other groups that combine migrants regardless of legal categories and statuses and often transcend national borders. However, the fact that national laws and law enforcement have an enormous impact in shaping patterns of migration flows and the individual experiences and social lives of migrants means that those legal categories become part of migrants' social and political identities and limit their economic, social, and cultural opportunities in the nations where they settle. While critiques of "methodological nationalism" can help researchers seeking to explain migration to become more aware of the particular and limited conceptual and analytic insights that can be drawn from nation states' administrative categories and data, these critiques must also enhance and inform our awareness of the extent to which nation state laws and policies do affect migrants' lives. 
The critique of "methodological nationalism" emerged from research that explored the transnational ties and communities of migrants, which seemed to create a social life that is not only alternative to nationalist expectations of immigration and assimilation but also, perhaps, a defense against, or escape from, the restrictions of nation states' migration laws and policies. But subsequent and critical empirical research about the extent to which migrants attempt and are able to construct and sustain transnational lives over their lifetimes and between generations suggests that the practice of transnationalism among migrants, who continue to be affected by national laws and policies, may be less prevalent in their livelihoods than the extent to which the concepts have captured the imagination of migration scholars (see for example Ozkul 2012; Portes et al. 2017; Portes 2001; Waldinger and Fitzgerald 2004). This comment is not meant to diminish either the insights that have been and can be derived from the concepts of "transnational migration" or "methodological nationalism" or the significance of the transnational ties for migrants. Rather I am suggesting that, in addition to welcoming a "softening of national models" as part of the globalization of migration theory, we should also encourage researchers to use the concepts of "transnationalism" and "methodological nationalism" to investigate and understand the full impact that the laws and policies of national states actually have on migrants, including states' engagements with transnational migrants (Portes and Fernández-Kelly 2015).

Regardless of one's views about what constitutes an appropriate application of the concept of "methodological nationalism," a growing attention to, or use of, the concept should not be conflated with the field's internationalization or globalization, especially for research that is designed to inform national or international public and policy debates. Further, although an analysis of co-authorship provides some indication of the extent to which research is becoming internationalized, it cannot reveal very much about "a broadening of conceptual and theoretical perspectives," the "softening of national models," or "the globalization of theory" (p. 4) without also examining the intellectual content of the articles. Though the Cross-Migration project's bibliometric analysis is not well-suited to represent the intellectual content of the field's globalization, ${ }^{6}$ it would help deepen our understanding of the nature of internationalized research if such an analysis could indicate how the research underlying internationally co-authored publications has been organized and focused, both geographically and topically.

In seeking to promote the internationalization of migration research through the SSRC, I have been particularly interested in the various ways in which international and interdisciplinary teams of researchers can be organized because of the potential for such teams to bringing about intellectual innovation. The different modes of organization and experiences of such projects organized by the SSRC indicate some of the variations, advantages, and challenges that are inherent in the different geographic foci and organizational approaches of internationalized research teams.

- Cross-Regional Comparisons of Research by Regionally-Based Researchers

${ }^{6}$ For a discussion of the theoretical use of national data to explain global relations between development and migration DeWind and Ergun (2013). 
The SSRC's International Migration Program's Sub-Committee on International Comparisons proposed to convene a working group of Asian and American scholars to compare both the migration patterns and migration research in Asia and the United States. When some of the American Sub-Committee members insisted that the Asian scholars be given a reading list of American publications but did not propose American scholars read a similar list of Asian publications, it seemed the project was unlikely to result in mutual learning between equals and the project was suspended. Inter-regional inequality between researchers and their paradigms is a constant issue in the internationalization of research, as we found in organizing subsequent international research projects.

- International Comparisons of Research by National Research Teams: The Children of Immigrants in Schools project compared research documenting the paths of immigrant children through schools into either higher education or the labor market in England, France, Netherlands, Spain, and the United States. Teams based in each country who researched and wrote about students' progress addressed a similar set of questions and modes of analysis in order to form an explanation of national differences. In part because of the national origins and foci of the research team members, drawing theoretical conclusions to explain international differences became more of a responsibility, or perhaps a privilege, for the project organizers than for the research team members.

- Nationally-Focused Research by International Research Teams

The Forced Migration and Human Rights project supported investigations by five research teams, each comprised of an academic scholar and a practitioner from an international humanitarian or human rights organization. Employing a human rights perspective, the teams investigated different aspects of the lives of internally and internationally-displaced forced migrants. In part because the research teams were for the most part international in composition, to give the project some comparative coherence, all the teams investigated forced migrants of only one nation, Sierra Leon. The project's success in helping the researchers' organizations employ research and human rights frameworks in designing assistance programs for forced migrants was diminished when their staff researchers moved on to other employment or education, career moves that were partly facilitated by their having participated in the project.

- Transnational Research by Nationally-Based Research Teams:

The Religious Lives of Migrant Minorities Project was organized internationally to investigate how immigrants settling in Johannesburg, Kuala Lumpur, and London used transnational religious ties to adapt to their different urban settings, all within the historical and geographical context of the British empire. The members of the teams based in London and Kuala Lumpur were comprised of national researchers but the Johannesburg team was international. Over 3 years the teams met together at each site to create a common set of investigative questions, research protocols, and an analytic framework with which to undertake and compare their research findings about the nature and significance of migrants' and their religions' transnational ties. Plans for collaborative writing both within and across research teams proved too complicated and difficult to achieve, partly due to concerns about "ownership" of the research findings. As a result, the final research reports were 
prepared for the most part by individual researchers at each site rather than internationally and collaboratively between the site teams.

- International Research Planning by International Groups of Researchers The SSRC's Dissertation Proposal Development Program organized seven international and interdisciplinary workshops to help graduate students prepare proposals to undertake dissertation research that may or may not have been international in scope. Each workshop included 12 graduate students and was led by two senior researchers. One half of each group was from the United States and the other half was from either France, the United Kingdom, or Southern Africa. The workshops were organized to help the students compare and learn from the different disciplinary research traditions in each country. In the first workshop, one notable exchange, which perhaps reflected differences in national perspectives, included American students challenging French students' research design saying, "You call those 'research methods'?" To which French students replied, challenging the American students' analyses of research data, "You call those 'theories'?" In subsequent workshops, better attuned to cross-national and interdisciplinary differences and sensitivities, we managed to organize more productive international exchanges. To what extent the workshops contributed to the formation of international research networks and international collaboration in research, as hoped, is still undetermined.

As indicated by each of these projects, the geographic scope and organization of internationalized research, which is not revealed by international co-authorships, can vary significantly. At the same time, the types migration flows being investigated by any project can be national, international, transnational, or some combination of different national and international configurations. While this is not the place to assess the innovative intellectual contributions of any particular mode of organizing international research, it has been my experience that it is the researchers who are successful in raising funds who get to choose, with donor approval, the research questions that will be pursued and to define the roles of other team members. Whether any project can or does generate innovative intellectual (or practical) contributions must be assessed when research is planned, carried out, and written up if only to justify and secure the significant financial and human resources that must be mobilized to organize and sustain international research.

The Cross-Migration article hints at the organizational and financial infrastructures that have supported and will be needed to expand the field's internationalization. These include educational and degree programs at universities, government and other agencies that create migration data, centers that mobilize and support research networks, organizations that can coordinate international research planning, and governmental and private funding agencies that will support various types of international research. The Cross-Migration article's analysis of international co-authorships suggests there are considerable disparities between nations and regions of the world regarding access to infrastructural and financial support for internationalized migration research. This unequal distribution of resources exists for all international research in the social sciences (DeWind and Gillett 2009). The experiences of the SSRC's international research projects described above indicate that, to promote intellectual innovation through 
international collaboration, disparities in access to resources and infrastructural support must be addressed and, to a great extent, equalized. Avoiding the hegemonic domination of the research goals and theoretical perspectives of researchers from relatively well-endowed countries is a considerable challenge in many different types of international research. No nationally-based donors with which I am familiar are willing to turn over the decision of what questions will be researched to researchers themselves, much less to researchers based in less-developed nations.

Whether and how resources for internationalized research become available and shared more equally will not be determined so much by what migration researchers might want or need but by funding agencies in deciding whether it is in their interest or mandate to support researchers' proposals. This concern about securing funding leads us to the politics of migration, the nature and importance of which in shaping the institutionalization of migration studies is a topic that the Cross-Migration project does not take up, in part no doubt because a bibliometric analysis could reveal little.

\section{Conclusion: the impact of migration and migration policy}

To conclude I take up two questions that the Cross-Migration article did not address directly but are significantly related not only to how but also to why migration studies have become institutionalized:

- What impact has migration itself had upon the geographic and topical scope of migration research?

- What effect has the engagement of migration researchers in public debates and policy making had upon the field?

The following, only partial, answers to these questions may help to explain how the field of migration studies has evolved and why it has become increasingly institutionalized.

\section{The impact of migration on migration studies}

Perhaps it is obvious that growth in the size and diversity of migration around the globe has given rise to migration studies as an international field. Conversely, were migration flows to subside, as it did during the mid-twentieth century in the United States and perhaps elsewhere, the field would likely diminish significantly despite its current level of institutionalization.

Looking more narrowly at one way in which migration's growth has influenced the field, a striking finding of the SSRC's earlier-mentioned National Survey of Immigration Scholars in the United States is an increase in the numbers and proportion of researchers who are themselves from immigrant backgrounds. In 1999 nearly half $(48 \%)$ of US immigration researchers were themselves first generation immigrants $(30 \%)$ or the children of immigrants (18\%). Among immigration researchers who had obtained doctoral degrees before 1965, 17\% were first generation immigrants, but after 1994 that figure increased to 35\%. The immigrant researchers were largely of Asian (Chinese, Korean, Filipino, and Indian) or Latin American and Caribbean (Mexican, Cuban, Puerto Rican, and Jamaican) national 
origins. Related to the increase of immigrant researchers was the increasing proportion of those who investigated migrants of their own national origin or ethnic group and who could be considered "insider" researchers. Of those who obtained doctoral degrees before 1965 only $25 \%$ were "insider" researchers but among those who obtained their degrees after 1994 some 40\% were (Rumbaut 2000). Perhaps the growing interest among migration researchers in the experiences of their own national origin or ethnic groups helps to account for what the Cross-Migration authors refer to as the "cultural turn' of migration research from being predominantly quantitative and demographic-focused, towards more nuanced qualitative studies of migration." (p. 5).

\section{The impact of policy making on migration studies}

Public debates about migration have had a significant impact on the priorities of research funders who, in turn, have determined what issues they would support migration researchers to address. The result has been a reinforcement of a hierarchy and fragmentation of the field between disciplines and between theoretical and policyoriented research, neither of which is revealed by the Cross-Migration bibliographic analysis.

In the United States, soon after the General Leonard Chapman, Commissioner of the US Immigration and Naturalization Service from 1973 to 1977, warned that the nation was the victim of "silent invasion" of illegal immigrants from Mexico, the director of the Central Intelligence Agency, William Colby, claimed that Mexican immigration was a greater threat to national security than the Soviet Union (Badillo-Veiga et al. 1979). So, the US Congress created a Select Commission on Immigration and Refugee Policy in order to determine the nature and impact of immigration on the United States and to propose revisions to US immigration law. The Select Commission was directed by Larry Fuchs, a professor of American Studies and a prominent immigration scholar. A decade later the Congress created similar Commission on Immigration Reform to again investigate immigration and propose legislation. Both commissions drew heavily on immigration scholars, sponsored research, and galvanized the growth of immigration studies in the United States. Both commissions published multiple volumes of commissioned and submitted research reports that were intended to influence and guide immigration legislation (Graham 2012).

By seeking research and testimony from the most authoritative scholars, both commissions unintentionally stimulated competition about what disciplines and methods of research were most credible. Economists, political scientists, and some sociologists promoted model-based and quantitative approaches to research and some frowned a bit on the more qualitative approaches to research of anthropologists, some sociologists, historians, and geographers. Such competition may have contributed to the fragmentation between disciplines that the Cross-Migration article posits was more typical of the field in the 1970s and 1980s than in more recent decades. Competition to influence policy makers reinforced a disciplinary hierarchy based on claims about which disciplines' methods are the "most scientific." 
In contrast, when the Andrew W. Mellon Foundation initially funded the SSRC to create an International Migration Program in 1994 in order to support theoretical research and the development of the field of migration studies, it declined the Council's proposal also to inform public debates and policy reforms related to migration. The foundation said the program's goal should be to "explain" migration, including the origins of government policies, not to "prescribe" migration policy. Other major foundations were similarly interested in supporting field-building research on migration related to specific issues such as religion, education, and development, among others. (See the Additional file 1 for a list of SSRC migration research topics and funders.) Perhaps because the SSRC's program was not trying directly to inform public debates or policy makers, at times we found it difficult to attract economists and quantitative political scientists to participate in our more theoretically-oriented and explicitly interdisciplinary working groups.

Interest among private philanthropies in the United States in supporting research related to the development of the field of migration studies has waned. Some have moved on to other concerns and others have devoted their resources to supporting advocacy to promote fair and equitable immigration policies. This focus on public policy prescription is reflected in the goals of the Grantmakers Concerned with Immigrants and Refugees, which describes itself as,

.... network of local, state, and national funders who seek to leverage their grantmaking to expand opportunities for and address challenges facing immigrants, refugees, and their communities. GCIR's work is guided by a fundamental belief in equal opportunity and justice, as well as a recognition that communities thrive when all of their members have the opportunity to contribute to the economic, cultural, social, and civic fabric ${ }^{7}$

That research that is policy-oriented continues to attract funding is illustrated by the list of over one-hundred donors who support the research and educational activities of the Migration Policy Institute (MPI). ${ }^{8}$ That there tends to be a divide between theoretical and policy-oriented research is illustrated by the near lack of response that MPI encountered when it tried to recruit the 109 fellows of SSRC's International Migration Program to write about the policy implications of their theoretically-oriented research.

A similar divide between theoretical and policy-oriented researchers likely exists in Europe, where I have been told there are two kinds of researchers: those who apply for research funding from the European Commission and those who do not. While the European Commission supports what seems to be theoretical or academic research as part of its mission to promote research and innovation, it also seeks generally to link that research to public policy goals and, more specifically, to link migration research to the European Commission's mission to manage immigration (European Commission 2016: 32 et passim.). Reflecting the influence of these funder goals, the conference organized to discuss the findings of the CrossMigration project, which was supported by the European Commission's Horizon 2020 program, was organized, according to the conference program, to assess both

\footnotetext{
${ }^{7}$ For more about the Grantmakers Concerned with Immigrants and Refugees, see https://www.gcir.org/. ${ }^{8}$ For a list of foundations supporting policy-related migration research, see https://www.migrationpolicy.org/ about/funders).
} 
the field's conceptual and theoretical development and its impact on how local, regional, and European Union government deal with issues of migration. Notably, while the opening conference session focused on the contributions of the article examined here, the six subsequent workshops focused, in various ways, on how migration researchers can cross the academic/policy divide and to respond to immigration policy priorities of the European Commission (IMISCOE, 2020).

Given the pressure by private and governmental research funders in the United States and Europe for migration researchers to address national policy concerns, it would be remarkable if, as part of the institutionalization of migration studies, researchers were able to escape the "methodological nationalism" seemingly inherent in the linkage between nation states' research priorities and goal of managing migration. Equally important for the field of migration studies, however, would be the recognition that not only the greater coherence of institutionalization but also the fragmentation between disciplines and between theoretical and policy research are co-existing and essential aspects of the field's constitution and development.

\section{Final thoughts and metaphorical representations}

Triangulating between quantitative bibliographic data, qualitative interviews with experts, and reference to seminal research publications, the Cross-Migration article presents us with an impressive overview of the culture of knowledge production within the field of migration studies. By focusing their analysis on co-authorship and co-citation networks, they have found increasing self-referencing, internationalization, and integration between and within epistemic communities among researchers in the field, which they convincingly conclude are strong indicators that the field has increasingly become institutionalized.

From the perspective of a blind man in touch with only one part of the elephant of migration studies I have sought to supplement what I have characterized to be the Cross-Migration article's skeletal portrait of the field. In sum, I have drawn the following observations from my limited experiences directing the organization of fieldbuilding activities at the SSRC:

- If the institutionalization of migration studies as an interdisciplinary field increases epistemic integration and homogenization at its core, perhaps we ought to encourage recognition of the differences of perspectives that can come from migration researchers' peripheral engagements with their different disciplines.

- No single definition of the topical, temporal, or geographic scope of migration studies can - or should be expected to - fully capture either the diversity of migrants, their movements, or their societal contexts. Nor can a single definition fully encompass the theoretical and political goals of researchers. Rather we should welcome multiple and even conflicting definitions of the field that suit its members' diverse purposes.

- To understand and promote the field's internationalization, in addition to considering co-authorship, we should also consider various permutations and combinations of geographic scope and topical foci of international research and the different modes of organizing collaborations between international researchers. 
- The field is more fragmented than the Cross-Migration analysis recognizes between theoretically and policy-oriented research and researchers. That private and government funders increasingly insist that researchers address national debates and policy concerns makes the development of theoretically-oriented research more difficult.

- The notion of "methodological nationalism" should be used to improve understandings of the significant impact that nation states and their migration policies have not only on migrants and but also on the questions, methods, and organization of both theoretical and policy-oriented research.

- Because the resources and infrastructures necessary to support internationally organized research are unequally distributed, those researchers with greater access to them have had disproportionate influence over the questions pursued in research. If "hegemonic homogenization" results, the innovative intellectual contributions expected from international perspectives will be diminished.

- As a complement to the quantitative representation of the field's institutionalization provided through the Cross-Migration Program's bibliographic analyses, perhaps metaphors - such as elephants, blind men, trees, and cans of worms - can provide researchers with additionally helpful ways of viewing and promoting the development of migration studies as an interdisciplinary field of research.

\section{Supplementary information}

Supplementary information accompanies this paper at https://doi.org/10.1186/s40878-020-00191-4.

Additional file 1.

Author's contributions

The author read and approved the final manuscript.

Competing interests

The author declares he has no competing interests.

Received: 1 May 2020 Accepted: 1 May 2020

Published online: 02 October 2020

References

Alba, R., Raboteau, A. J., \& DeWind, J. (2009). Immigration and Religion in America, Comparative and Historical Perspectives. New York: New York University Press.

Badillo-Veiga, A., DeWind, J., \& Preston, J. (1979). Undocumented immigrant Workers in New York City. The NACLA Report on the Americas, XIII (6): 2-46. New York: North American Congress on Latin America.

Bommes, M., \& Morawska, E. (2005). International migration research: Constructions, omissions and the promises of Interdisciplinarity. Farnham: Ashgate.

Card, D. (1990). The Impact of the Mariel Boatlift on the Miami Labor Market. Industrial and Labor Relations Review, $43(2), 245-257$

Card, D., DiNardo, J. E., \& Estes, E. (2000). The More Things Change: Immigrants and the Children of Immigrants in the 1940s, the 1970s, and the 1990s. In G. J. Borjas (Ed.), Issues in the Economics of Immigration (pp. 227-270). Chicago: Chicago University Press.

Chang, C., \& DeWind, J. (2002). The international migration fellowship program: Seven years. Items \& Issues, 4(1), $20-25$. Retrieved from https://issuu.com/ssrcitemsissues/docs/i_i_vol_4_no_1_2003?e=24618429/35326188.

Cohen, R. (1996). Theories of migration. Cheltenham: Edward Elgar.

DeWind, J. (2019). "The Problem with Migration Studies and Policy Making: Their Preoccupation with Migrants", paper presented to the "Global Migration Conversation", Zolberg Institute on Migration and Mobility, New School University, New York City on June 6th.

DeWind, J. (2000). Immigration studies and the Social Science Research Council. In N. Foner, R. G. Rumbaut, \& S. Gold (Eds.), Immigration Research for a New Century, Multidisciplinary Perspectives (pp. 69-75). New York: Russell Sage Foundation.

DeWind, J., \& Ergun, D. (2013). Development and migration: Historical trends and future research. In J. Cortina, \& E. OchoaReza (Eds.), New perspectives on international migration and development (pp. 5-42). New York: Columbia University Press.

DeWind, J., \& Gillett, J. (2009). Funding Agency Support for the Social Sciences in Countries with Developing and Transition Economies, Committee on Developing and Transition Economies (CODATE), International Social Science Council. (Unpublished report)

European Commission. (2016). Strategic plan 2016-2020: Directorate-General for Research and Innovation. Brussels: European Commission. 
Foner, N., \& Fredrickson, G. (Eds.). (2005). Not Just Black and White, Historical and Contemporary Perspectives on Immigration, Race, and Ethnicity in the United States. New York: Russell Sage Foundation.

Gerstle, G., Molenkopf, J. H. (Eds.). (2001). E Pluribus Unum, Contemporary and Historical Perspectives on Immigrant Political Incorporation. New York: Russell Sage Foundation.

Graham, O. L. (2012). National Commissions on immigration, 1907-1997. Center for Immigration Studies. https://cis.org/ Graham-Jr/National-Commissions-Immigration-19071997. Accessed 12 June 2020.

IMISCOE. (2020). The Coming of Age of Migration Studies, Debating the Evolution and Impact of a Research Field. University of Lisbon, Institute of Geography and Spatial Planning, 5-6 February. http://ceg.ulisboa.pt/wp-content/uploads/2020/02/ Final-programme-1.pdf.

King, R. (2012). Theories and typologies of migration: An overview and a primer (Willy Brandt Series of Working Papers in International Migration and Ethnic Relations 3/12). Malmö: Malmö Institute for Studies of migration, Diversity and Welfare (MIM).

Levy, N., Pisarevskaya, A., \& Scholten, P. (2020). Between fragmentation and institutionalisation: the rise of migration studies as a research field. Comparative Migration Studies, 8. https://doi.org/10.1186/s40878-020-00180-7

Massey, D. S., Arango, J., Hugo, G., Kouaouci, A., \& Pellegrino, A. (1998). Worlds in motion: Understanding international migration at the end of the millennium. Oxford: Clarendon Press.

Ozkul, D. (2012). Transnational migration research. Sociopedia.lsa, 1-12. https://www.researchgate.net/profile/Derya_Ozkul/ publication/267512014_Ozkul_Derya_2012_'Transnational_Migration_Research'_Sociopediaisa/links/5bc5d55a458515 f7d9bf5e4d/Ozkul-Derya-2012-Transnational-Migration-Research-Sociopediaisa.pdf. Accessed 19 Jan 2020.

Pisarevskaya, A., Levy, N., Scholten, P., \& Jansen, J. (2019). Mapping migration studies: An empirical analysis of the coming of age of a research field. Migration Studies, mnz031. https://doi.org/10.1093/migration/mnz031.

Portes, A. (1987). The Social Origins of the Cuban Enclave Economy of Miami. Sociological Perspectives, 30(4), 340-372. https:// doi.org/10.2307/1389209.

Portes, A. (2001). Introduction: The debates and significance of immigrant transnationalism. Global Networks, 1(3), 181-194.

Portes, A. (2010). Economic sociology: A systematic inquiry. Princeton University Press.

Portes, A., \& Fernández-Kelly, P. (2015). The state and the grassroots: Immigrant transnational organizations in four continents. New York and Oxford: Berghahn Books.

Portes, A., \& Jensen, L. (1987). What's an Ethnic Enclave? The Case for Conceptual Clarity. American Sociological Review 52(December), 768-771.

Portes, A., \& Jensen, L. (1989). The Enclave and the Entrants: Patterns of Ethnic Enterprise in Miami before and after Mariel. American Sociological Review, 54(6), 929-949. https://doi.org/10.2307/2095716.

Portes, A., \& Jensen, L. (1992). Disproving the Enclave Hypothesis: Reply. American Sociological Review, 57(3), 418-420. https:// doi.org/10.2307/2096246.

Portes, A., Guarnizo, L. E., \& Landolt, P. (2017). Commentary on the study of transnationalism: Pitfalls and promise of an emergent research field. Ethnic and Racial Studies, 40(9), 1486-1491. https://doi.org/10.1080/01419870.2017.1308528

Portes, A., \& Puhrmann, A. (2015). A bifurcated enclave: The economic evolution of the Cuban and Cuban-American population of metropolitan Miami. Cuban Studies, 43, 40-63.

Portes, A., \& Shafer, S. (2007). Revisiting the enclave hypothesis: Miami twenty-five years later. Research in the Sociology of Organizations, 25, 157-190.

Portes, A., \& Zhou, M. (1993). The new second generation: Segmented assimilation and its variants. The Annals of the American Academy of Political and Social Science, 530(1), 74-96.

Rumbaut, R. G. (2000). Immigration research in the United States: Social origins and future orientations. In N. Foner, R. G. Rumbaut, \& S. Gold (Eds.), Immigration Research for a New Century, Multidisciplinary Perspectives (pp. 23-43). New York: Russell Sage Foundation.

Waldinger, R., \& Fitzgerald, D. (2004). Transnationalism in question. American Journal of Sociology, 109(5), 1177-1195.

\section{Publisher's Note}

Springer Nature remains neutral with regard to jurisdictional claims in published maps and institutional affiliations.

\section{Submit your manuscript to a SpringerOpen ${ }^{\circ}$ journal and benefit from:}

- Convenient online submission

- Rigorous peer review

- Open access: articles freely available online

- High visibility within the field

- Retaining the copyright to your article

Submit your next manuscript at $\boldsymbol{s p r i n g e r o p e n . c o m ~}$ 